\title{
Heavy Metals as Impurities in the Bayer Production Cycle of the Aluminum Hydroxide from Sierra Leone Bauxite. Preliminary Study
}

\author{
Gheorghe Dobra ${ }^{a}$, Sorin Iliev \\ Lucian Cotet ${ }^{\mathrm{b}}$, Alina Boiangiu*b, \\ Iosif Hulkac, Lidia Kim, \\ Gina Alina Catrina ${ }^{d}$ and Laurentiu Filipescu ${ }^{b}$ \\ a Alro Slatina \\ Slatina, Romania \\ ${ }^{b}$ Alum Tulcea \\ Tulcea, Romania \\ ${ }^{c}$ Universitatea Politehnica Timisoara \\ Timisoara, Romania \\ 'INCD Ecoind \\ Bucuresti, Romania
}

Received 12.12.2020, received in revised form 07.02.2021, accepted 21.03.2021

\begin{abstract}
This paper is reporting the data of a preliminary study on heavy metals distribution in the fluid and solid phases involved in dry and classified aluminium hydroxide production through Bayer process. For heavy metals released in the fluid phases, the main source of contamination is the bauxite through its mineralogical phases soluble or insoluble in alkaline solution. It was shown that predominant way to transfer contaminating elements in aluminium hydroxide particles is the occlusion of very fine particles coming from mineralogical phases of bauxite residue. New born mineralogical phases from bauxite residue, like poor crystallized sodalite and cancrinite, are the most active occlusion contaminants.
\end{abstract}

Keywords: aluminium hydroxide, heavy metals, occlusion, bauxite, bauxite residue, Bayer process.

Citation: Dobra G., Iliev S., Cotet L., Boiangiu A., Hulka I., Kim L., Catrina G. A., Filipescu L. Heavy metals as impurities in the bayer production cycle of the aluminum hydroxide from Sierra Leone bauxite. Preliminary study, J. Sib. Fed. Univ. Eng. \& Technol., 2021, 14(2), 151-165. DOI: 10.17516/1999-494X-0296

(C) Siberian Federal University. All rights reserved

This work is licensed under a Creative Commons Attribution-Non Commercial 4.0 International License (CC BY-NC 4.0).

* Corresponding author E-mail address: aboiangiu@alum.ro 


\title{
Тяжелые металлы как примеси
}

\section{в байерном производственном цикле \\ гидроксида алюминия из сьерра-леонбуксита. \\ Предварительное исследование}

\author{
Георге Добра ${ }^{a}$, Сорин Илий, Луциан Котец ${ }^{\sigma}$, \\ Алина Боиангиу ${ }^{\sigma}$, Джозеф Хулка ${ }^{\mathrm{B}}$, Лидия Ким \\ Джина Алина Цатринаг, Лауренцию Филипеску ${ }^{\sigma}$ \\ аллро Слатина \\ Румыния, Слатина \\ ${ }^{\sigma}$ Alum Tulcea \\ Румыния, Тулча \\ ${ }^{в}$ Политехнический университет Тиминоарь \\ Румыния, Тимишоара \\ ${ }^{2} I N C D$ Ecoind \\ Румыния, Бухарест
}

\begin{abstract}
Аннотация. В этой статье приводятся данные предварительного исследования распределения тяжелых металлов в жидкой и твердой фазах, участвующих в производстве сухого и классифицированного гидроксида алюминия в процессе Байера. Для тяжелых металлов, выделяющихся в жидких фазах, основным источником загрязнения является боксит через его минералогические фазы, растворимые или нерастворимые в щелочном растворе. Было показано, что преобладающим способом переноса загрязняющих элементов в частицах гидроксида алюминия является окклюзия очень мелких частиц, происходящих из минералогических фаз бокситового остатка. Новорожденные минералогические фазы из бокситовых остатков, такие как плохо кристаллизованный содалит и канкринит, являются наиболее активными загрязняющими примесями.
\end{abstract}

Ключевые слова: гидроксид алюминия, тяжелые металлы, окклюзия, бокситы, бокситовый остаток, байерский процесс.

Цитирование: Добра, Георге. Тяжелые металлы как примеси в байерном производственном цикле гидроксида алюминия из сьерра-леонбуксита. Предварительное исследование / Георге Добра, Луциан Котец, Сорин Илии, Алина Боиангиу, Джозеф Хулка, Лидия Ким, Джина Алина Цатрина, Лауренцию Филипеску // Журн. Сиб. федер. ун-та. Техника и технологии, 2021, 14(2). С. 151-165. DOI: 10.17516/1999-494X-0296

\section{Introduction}

In the alumina industry, the main sources of heavy metals are bauxite, as a raw material, auxiliary products with heavy metal content (lime, additives used to control process parameters and other materials used for proper operation and maintenance of the equipment). The transition of heavy metals from bauxite into the Bayer production cycle (and hence, contamination of the alumina, by-products and residual products) is part of a specific way of distribution and contamination with heavy metals, characteristic for each type of processed bauxite or each application variant of the alumina Bayer process. Ultimately, the entire process is dependent on the technological efficiency of the equipment used and on the particular parameters adopted as optimal in each production unit. 
Alum SA Tulcea, Romania, uses only one type of bauxite - lateritic bauxite from Sierra Leone. From this point of view, there is a significant advantage in controlling the entire technological process, mainly in terms of products contamination factors and mindful environmental management. In addition, compared to other types of bauxite available for processing in the aluminium industry, lateritic bauxites are purer and easier to process than karst bauxites. Thus, the following significant mineralogical and chemical particularities were identified in defining the technological value of bauxite in Sierra Leone (i. e. the advantages and disadvantages of using this type of bauxite in the manufacture of alumina): a) The major mineralogical components identified in the bauxite samples were gibbsite (30-40\% available $\mathrm{Al}_{2} \mathrm{O}_{3}$ ), alumino-goethite (20-30\%) and alumino-hematite (less than $5 \%$ ); b) The entire mass of $\mathrm{Fe}_{2} \mathrm{O}_{3}$ consists only of solid solutions: alumino-goethite and alumino-hematite, compounds that incorporate large amounts of non-extractable $\mathrm{Al}_{2} \mathrm{O}_{3}$ and intensify the process of boehmitic reversal in the settling and washing vessels of bauxite residue, increasing the residue factor from 1.5 to 2.3 and producing relatively higher losses of $\mathrm{Na}_{2} \mathrm{O}$; c) The minor mineralogical components of bauxite are: kaolin, quartz, zircon, ilmenite, rutile and anatase, but their concentration is relatively low compared to the major constituents; d) Approximately 30-40 \% of the mineralogical phases from Sierra Leone bauxite are in an amorphous state, but most of these amorphous phases come from the crystalline components listed above due to excessive wear during the formation of bauxite deposit and its subsequent metamorphic transformations; e) Experimental data collected after the digestion stage of this type of bauxite have shown that a compact mass of approximately 50-55\% of bauxite passes completely untransformed through all the previous technological stages of the Bayer process; f). The major mineralogical components identified in the bauxite residue are: alumino - goethite (30-35\%), alumino-hematite (approximately 12-15\%) and sodalite - cancrinite - katoite mixtures 20-25\%); g) The minor mineralogical components of the bauxite residue are: gibbsite, calcite and other alkaline earth carbonates and sulfates, quartz, rutile, anatase and others at very low concentrations; h) The soluble components of alumino-gibbsitic bauxite from Sierra Leone are concentrated up to the solubility limit in the Bayer concentrated liquors and are unevenly distributed between the spent liquor and the bauxite residue. Bayer liquors transport and contaminate fluids throughout the entire technological cycle, but only a tiny portion reaches the finished products. The rest accumulates in the bauxite residue $[1,2]$.

The purpose of this paper is to conduct a preliminary study on the distribution of impurities in the Bayer cycle of manufacturing aluminium hydroxide and calcined alumina in a short period, before and during experiments on the manufacture of dry and classified hydrate sorts. The paper does not aim to highlight the purity of the fluids and solid phases from the production line, but only to identify the sources of contamination and the ways to eliminate or alleviate contamination of the final products.

\section{Experimental part}

\subsection{Sample collection and chemical analysis}

Determination of the heavy metal content in fluid and solid phases from the aluminium hydroxide production cycle was performed after starting of all research facilities for development of a technology for obtaining wet, dry, ground and classified aluminium hydroxide. These equipment were acquired under the project co-funded by the European Regional Development Fund through the Competitiveness Operational Program 2014-2020 «Endow the research and Development of SC ALUM SA with independent and efficient research facilities to support the economic competitiveness and business 
development»: «Independent equipment / Installation for research and development of the technology of wet aluminium hydroxide classification», «Independent equipment / Installation for research and development of technology to obtain the dried aluminium hydroxide» and «Independent equipment / Installation for research and development of the technology of grinding and screening the dried aluminium hydroxide».

Firstly, during the experiments, representative samples of bauxite, concentrated and spent Bayer liquors were collected in a few rounds. Then, some hours before all the equipment were shut down, representative samples of bauxite residue and aluminium hydroxide were also collected from previously scheduled points of measurements for the present preliminary test study. The multiple samples collected at each sampling point for heavy metals determination were cumulated and mediated and then, sent to laboratory for analyses. Sampling and analysis of each element of interest were done in accordance with European standards. The actual determinations of heavy metals concentration in the liquid and solid phases were performed using the ICP-OES and the ICP-MS method, both recommended by the above-mentioned standards.

\subsection{Mineralogical analysis}

Acquisition of data was achieved on the BRUKER D8 ADVANCE diffraction instrument by means of the DIFFRAC plus XRD Commander (Bruker AXS) software through the Bragg-Brentano diffraction method, coupling $\Theta-\Theta$ on vertical configuration. The data processing was performed by means of the DIFFRAC plus BASIC Evaluation Package software, version EVA12, 2006 of the software package containing DIFFRAC plus BASIC (Bruker AXS) and the data base ICDD PDF-2 Release 2006. Other details were given in [2].

\subsection{Microscopical analysis}

The morphology and elemental composition of the particulate material samples (bauxite, bauxite residue and aluminium hydroxide) was characterized by scanning electron microscopy (SEM: Quanta FEG 250, FEI, The Netherlands) using back scattered electron detector (BSD) coupled with energy dispersive X-ray spectroscopy (EDS: using Apollo SSD detector, EDAX Inc. US). The microstructure and EDS analysis were performed at about $10 \mathrm{~mm}$ working distance (WD) in low vacuum mode in order to avoid surface charging and damage of the analysed material.

\section{Experimental data}

\subsection{Heavy metals}

The analysed heavy metals were divided into two groups: the heavy metal group with medium toxicity potential and the heavy metal group with high toxicity potential. The group of heavy metals with medium toxicity potential included total chromium summing trivalent chromium (insoluble in Bayer liquors) and hexavalent chromium, and the group of heavy metals with high toxicity potential included hexavalent chromium (soluble in water and Bayer liquors). This partitioning is justified by the fact that in Bayer liquors, the reducing character is predominating, and the chance of trivalent chromium to oxidize in the manufacturing cycle of aluminium hydroxide is zero.

In the case of bauxite residue stored in monitored dumps, the chance of trivalent chromium to oxidize is minimal, and as a result, only small amounts of hexavalent chromium were found in the 
bauxite residue. Also, the results of our previous research corroborated with other data from the literature [3-6] show that changing the $\mathrm{pH}$ of Bayer liquors does not affect the status of chromium in these liquors.

In the Tables 1 and 2 and in the Fig. 1 and 2 there are presented the experimental data, with the mention that in Table 1 and Fig. 1, the concentrations are expressed in ppm, and in the Table 2 and Fig. 2, the concentrations are expressed in ppb. These data show that bauxite has a moderate content of impurities, similar to that of other types of lateritic bauxite. Only the mineralogical peculiarities, specific to the alumino-goethite bauxites, make the difference in terms of the contamination capacity of aluminium hydroxide through the mechanisms of surface absorption and occlusion, respectively.

The total chromium concentration can be considered quite normal, because this element is one of the minor components of bauxite, and chromium compounds (chromites) are insoluble in Bayer liquors. As a source of pollution, only hexavalent chromium should be thoroughly considered, as was shown above. Cadmium, arsenic and mercury are found in common concentrations throughout the Bayer circuit when Sierra Leone bauxite is processed. Their concentration in aluminum hydroxide are laying close to the detection limit and could not raise suspicions. The real sources of pollution of aluminum hydroxide are copper and zinc with concentrations of tens of ppm in bauxite. Diminishing of the copper and zinc content in Bayer liquors is possible by concentrating the spent liquors up to 250-300 $\mathrm{g} / \mathrm{L} \mathrm{Na}{ }_{2} \mathrm{O}$ and precipitating these elements together with the organic compounds and respectively, by discharging them in the crusts, and eventually, eliminating them together as production waste. As for copper, zinc, lead and total chromium, these elements might be taken up by the freshly precipitated aluminum hydroxide, as particulate occlusions. In this case, reduction of the content of copper, zinc,

Table 1. Elements from class of heavy metals with medium toxic potential in the manufacturing cycle of aluminium hydroxide

\begin{tabular}{|l|c|c|c|c|}
\hline \multicolumn{1}{|c|}{ Source/Elements } & Zinc, $\mathrm{Zn}$ & Copper, $\mathrm{Cu}$ & Lead, $\mathrm{Pb}$ & Chromium, $\mathrm{Cr}$ \\
\hline Bauxite, ppm & 15,38 & 36,29 & 18,60 & 233.5 \\
\hline Bauxite residue, ppm & 46.60 & 68,70 & 12,39 & 541.0 \\
\hline Bayer concentrated liquor, ppm & 23.2 & 5.23 & 0.77 & 5.32 \\
\hline Bayer spent liquor, ppm & 0,15 & 0,04 & $<0,007$ & 0,118 \\
\hline Aluminium hydroxide, ppm & 0,404 & 2,771 & 0,995 & 0,282 \\
\hline
\end{tabular}

Table 2. Elements from the class of heavy metals with high toxic potential in the manufacturing cycle of aluminium hydroxide

\begin{tabular}{|l|c|c|c|c|}
\hline \multicolumn{1}{|c|}{ Source/Elements } & Chromium, $\mathrm{Cr}^{6+}$ & Cadmium, Cd & Arsenic, As & Mercury, $\mathrm{Hg}$ \\
\hline Bauxite, $\mathrm{ppb}$ & 50 & 190 & 1668 & 230 \\
\hline Bauxite residue, $\mathrm{ppb}$ & 50 & 384 & 857 & 110 \\
\hline Bayer concentrated liquor, ppb & 60 & 18 & 1000 & 200 \\
\hline Bayer spent liquor, ppb & 40 & 40 & 40 & 39 \\
\hline Aluminium hydroxide, ppb & 50 & 80 & 40 & 50 \\
\hline
\end{tabular}




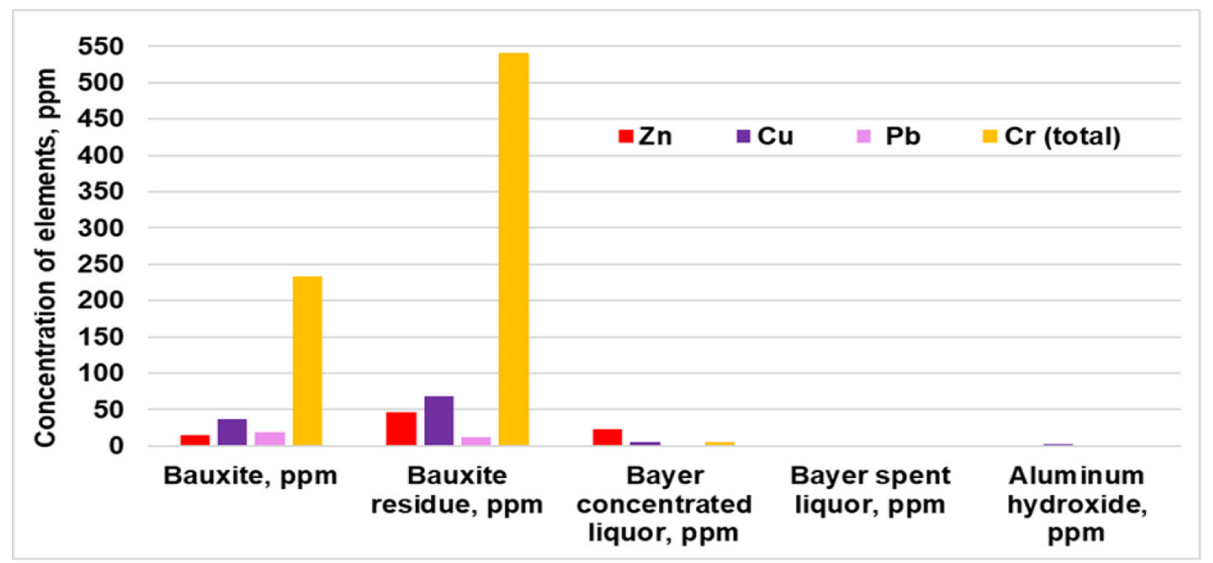

Fig. 1. Elements from the class of heavy metals with moderate toxic potential in the manufacturing cycle of aluminium hydroxide

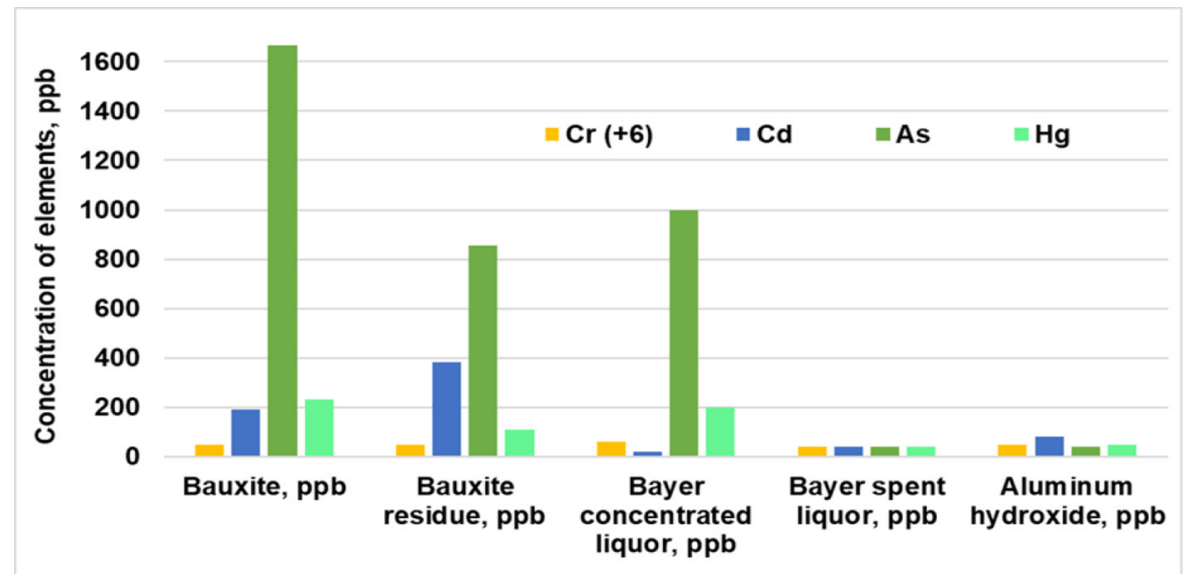

Fig. 2. Elements from the class of heavy metals with high toxic potential in the manufacturing cycle of aluminium hydroxide

lead and chromium will be done in fine filtration stage of the Bayer concentrated liquors, i. e. in red filtration, where new filters and new filter membranes with better performance than those currently used are needed.

The measured concentrations from the Tables 1 and 2, and the Fig. 1 and 2 are in good agreement with the data provided by other alumina production units. An edifying example about the level of contamination is the content of heavy metals in bauxite residue given bellow: cadmium $(\mathrm{Cd}, 1.3 \mathrm{ppm}$ and $\mathrm{Rfc}-2)$, total chromium (Cr, $1350 \mathrm{ppm}$ and $\mathrm{Rfc}-80)$, copper ( $\mathrm{Cu}, 52 \mathrm{ppm}$ and $\mathrm{Rfc}-50)$, lead $(\mathrm{Pb}, 50 \mathrm{ppm}$ and $\mathrm{Rfc}-100)$, nickel (Ni, $80 \mathrm{ppm}$ and Rfc-75), mercury (Hg, $0.3 \mathrm{ppm}$ and $\mathrm{Rfg}-1)$, arsenic (As, $1.0 \mathrm{ppm}$ and $\mathrm{Rfc}-50$ ), zinc (Zn, $80 \mathrm{ppm}$ and $\mathrm{Rfc}-300)$, cobalt (Co $16.0 \mathrm{ppm}$ and Rfc 40), manganese (Mn, $406 \mathrm{ppm}$ and $\mathrm{Rfc}-850$ ), antimony ( $\mathrm{Sb}, 0.1 \mathrm{ppm}$ and $\mathrm{Rfc}-6$ ), and selenium ( $\mathrm{Se}$, 4.0 and $\mathrm{Rfc}-5$ ). The Rfc specification is the reference concentration (in milligrams per kilogram) of toxic metals in soils, set by the Spanish authorities for the protection of human health (RD60/2009, 26 February 2009), taking into account the risks of water contamination and / or the risks of increasing 
phytotoxicity in agriculture, land use, animal husbandry and forest protection [7-9]. In addition, due to the low concentrations of heavy metals there is practically not a concentration process of these elements in Bayer liquors, but only an accumulation in the bauxite residue. At most, tiny amounts appear as a surface contamination of the aluminum hydroxide [10].

An analysis model of the heavy metals distribution in Bayer cycle is offered by the Greek company Mytilineos SA, Agios Nikolaos, Viotia, Greece [11], This company processes two types of bauxite: a local karstic bauxite (diasporic bauxite) and a lateritic bauxite purchased on the lateritic bauxite market, preferably a very reactive gibbsitic bauxite. The processed karstic bauxite comes from the ParnassusGiona area and has the following mineralogical composition: 10-30\% boehmite, 20-50\% diaspore, 20-25\% hematite, $1-5 \%$ calcite, $1-2 \%$ quartz, $1-5 \%$ kaolinite and $0.5-2 \%$ anatase [12]. Lateritic bauxite processed along with karstic one is a known gibbsitic bauxite, not quite similar to Sierra Leone bauxite, because the iron is found in this type of bauxite only as hematite.

In the Table 3 there is shown the distribution of arsenic, chromium and vanadium in the main material flows of Bayer suitable variant technology for the raw materials described above. For other heavy metals the table refers only to the composition of concentrated and spent liquors. Comparing the data from Table 3 with those from Tables 1 and 2, and with Fig. 1 and 2, we can observe similarities and differences due exclusively to the mineralogical peculiarities of both bauxites.

Table 3. Heavy metals distribution in Bayer cycle at Mytilineos S.A., Agios Nikolaos, Greece

\begin{tabular}{|l|c|c|c|c|c|c|c|c|}
\hline \multicolumn{1}{|c|}{ Elements } & As & Cr & Mo & Ni & Si & V & W & Y \\
\hline Concentrated Bayer liquor, ppm & 110.8 & 1.4 & 318 & 4.8 & 544 & 295.2 & 2.27 & $<0.04$ \\
\hline Bauxite residue, ppm & 189 & 1265 & & & & 903 & & \\
\hline Bayer spent liquor, ppm & 99.6 & 1.3 & 273 & $<4$ & 520 & 3614 & 7.21 & $<0.04$ \\
\hline Aluminium hydroxide, ppm & $<5$ & $<5$ & & & & $<10$ & & \\
\hline
\end{tabular}

The excess of chromium and vanadium in fresh and recycled Bayer liquors is justified not only by the high concentrations of these elements in karstic bauxite, but also by the fact that these elements usually accumulate in the liquors till the saturation, as is the case of all bauxites rich in these elements. Nevertheless, the chromium, although found in higher concentrations in karstic bauxites, accumulates only in the bauxite residue. In both cases, the concentrations of these three elements remain at very low values in the aluminum hydroxide.

\subsection{Radioactive metals}

In the last years there were made two integral reports on radioactivity level on the production line of the aluminium hydroxide. First report confirmed some older measurement data on rare occurrence of radio-nuclides in the Sierra Leone bauxite and in the bauxite residue disposal site at Alum SA Tulcea. In the second report, it turned out that concentrations of gamma radiation of radio-nuclides in the bauxite residue are mostly below the minimum detectable activity-AMD, according the ISO 11920/2010. Also, the total radioactivity level, measured on bauxite residue samples, is below the soil natural radioactivity, 
which is about $40 / \mathrm{Bq} / \mathrm{kg}$. Both tests corroborate the conclusion that Sierra Leone bauxite used as raw materials in the production of alumina at Alum SA Tulcea does not contain radio-nuclides. The data are systematically presented in the Table 4 .

Table 4. Radioactivity on Bayer aluminum hydroxide production line

\begin{tabular}{|c|c|c|c|}
\hline Samples & Experimental results & $\begin{array}{l}\text { Radioactive } \\
\text { concentration/ } \\
\text { radionuclide, } \\
\text { units, } \mathrm{Bq} / \mathrm{kg}\end{array}$ & $\begin{array}{l}\text { Estimated } \\
\text { uncertainty } \\
\quad(\mathrm{k}=1)\end{array}$ \\
\hline 1 & 2 & 3 & 4 \\
\hline $\begin{array}{l}\text { A. Sample } 2 \text { - Sierra Leone bauxite } \\
\text { A. The measurement in a plastic Sarpagan } \\
\text { type (diameter } 78 \mathrm{~mm} \text {, height } 42 \mathrm{~mm}) \text {, } \\
\text { total mass sample }(0,2099 \pm 0,0010) \mathrm{kg} \text {, } \\
\text { measurement duration } 25200 \mathrm{~s} \text {, on a } \\
\text { plinth at a distance of } 1,6 \mathrm{~mm} \text { in the } \\
\text { central position over detector }\end{array}$ & $\begin{array}{l}\text { Natural radionuclide }{ }^{40} \mathrm{~K}: \\
\text { Natural radioactive series of } \\
\text { thorium }\left({ }^{232} \mathbf{T h}\right): \\
\\
{ }^{226} \mathrm{Ra} \text {, from Natural } \\
\text { radioactive series of uranium: }\end{array}$ & $\begin{array}{l}\text { AMD * } \\
15,7 \mathrm{~Bq} / \mathrm{kg} \\
38 \mathrm{~Bq} / \mathrm{kg} \\
\text { (on the reference data } \\
07.11 .2017,12: 00 \mathrm{UT} \text { ) }\end{array}$ & $\begin{array}{l}2,4 \mathrm{~Bq} / \mathrm{kg} \\
\pm 8 \mathrm{~Bq} / \mathrm{kg}\end{array}$ \\
\hline
\end{tabular}

*AMD: minimum detectable activity in this case estimated to $6,3 \mathrm{~Bq} / \mathrm{kg}$ for ${ }^{40} \mathrm{~K}$. Radionuclides from the natural radioactive series of thorium detected in samples are: ${ }^{228} \mathrm{Ac}$ (emissions gamma radiations with 338 $\mathrm{keV}),{ }^{212} \mathrm{~Pb},{ }^{212} \mathrm{Bi}$ and ${ }^{208} \mathrm{Tl}$. Radionuclides from the natural radioactive series of uranium detected in samples are: ${ }^{234} \mathrm{Th},{ }^{214} \mathrm{~Pb} s \mathrm{~s}^{214} \mathrm{Bi}$ (the last two are descendents of ${ }^{226} \mathrm{Ra}$, from series ${ }^{238} \mathrm{U}$ and ${ }^{226} \mathrm{Ra}$

\begin{tabular}{|c|c|c|c|}
\hline $\begin{array}{l}\text { B. Sample } 4 \text { - Sierra Leone bauxite } \\
\text { B. The measurement in a plastic } \\
\text { Sarpagan type (diameter } 78 \mathrm{~mm} \text {, } \\
\text { height } 42 \mathrm{~mm} \text { ), total mass sample } \\
(0,1966 \pm 0,0010) \mathrm{kg} \text {, The measurement } \\
\text { duration } 24.000 \mathrm{~s} \text {, on a plinth at a } \\
\text { distance of } 1,6 \mathrm{~mm} \text { in the central } \\
\text { position over detector }\end{array}$ & $\begin{array}{l}\text { Natural radionuclid }{ }^{40} \mathrm{~K} \text { : } \\
\text { Natural radioactive series of } \\
\text { thorium }\left({ }^{232} \mathrm{Th}\right) \text { : } \\
{ }^{226} \mathrm{Ra} \text {, from natural radioactive } \\
\text { series of uranium: }\end{array}$ & $\begin{array}{l}10 \mathrm{~Bq} / \mathrm{kg} \\
15,1 \mathrm{~Bq} / \mathrm{kg} \\
22 \mathrm{~Bq} / \mathrm{kg} \\
\text { (on the reference data } \\
07.11 .2017,12: 00 \mathrm{UT} \text { ) }\end{array}$ & $\begin{array}{l} \pm 5 \mathrm{~Bq} / \mathrm{kg} \\
\pm 2,4 \mathrm{~Bq} / \mathrm{kg} \\
\pm 7 \mathrm{~Bq} / \mathrm{kg}\end{array}$ \\
\hline
\end{tabular}

Radionuclides from the natural radioactive series of thorium detected in samples are: ${ }^{228} \mathrm{Ac}$ (emissions gamma radiations with $338 \mathrm{keV}$ ), ${ }^{212} \mathrm{~Pb},{ }^{212} \mathrm{Bi}$ and ${ }^{208} \mathrm{Tl}$. Radionuclides from the natural radioactive series of uranium detected in samples are: ${ }^{234} \mathrm{Th},{ }^{214} \mathrm{~Pb} s \mathrm{~s}^{214} \mathrm{Bi}$ (the last two are descendents of ${ }^{226} \mathrm{Ra}$, from series ${ }^{238} \mathrm{U}$ and ${ }^{226} \mathrm{Ra}$

\begin{tabular}{|c|c|c|c|}
\hline $\begin{array}{l}\text { C. Sample } 1 \text { - Bayer mother liquor. The } \\
\text { measurement in a plastic Marinelli type } \\
\text { with the volume } 0,9 \mathrm{~L} \text {, total mass sample } \\
(1,0574 \pm 0,0010) \mathrm{Kg} \text {, measurement } \\
\text { duration } 25.000 \mathrm{~s} \text {, with the sample in the } \\
\text { central position, directly on detector }\end{array}$ & $\begin{array}{l}\text { Natural radionuclide }{ }^{40} \mathrm{~K}: \\
\text { Natural radioactive series of } \\
\text { thorium }\left({ }^{232} \mathrm{Th}\right): \\
{ }^{226} \mathrm{Ra} \text {, from Natural } \\
\text { radioactive series of uranium }\end{array}$ & $\begin{array}{l}5,3 \mathrm{~Bq} / \mathrm{kg}< \\
\mathrm{AMD}^{*} \\
4,1 \mathrm{~Bq} / \mathrm{kg} \\
\text { (on the reference data } \\
07.11 .2017,12: 00 \mathrm{UT})\end{array}$ & $\begin{array}{l} \pm 1,0 \mathrm{~Bq} / \mathrm{kg} \\
\pm 1,0 \mathrm{~Bq} / \mathrm{kg}\end{array}$ \\
\hline
\end{tabular}

Radionuclides from natural radioactive series of the torium detected in samples, were: ${ }^{228} \mathrm{Ac},{ }^{212} \mathrm{~Pb},{ }^{212} \mathrm{Bi}$ şi ${ }^{208} \mathrm{Tl}$. Radionuclides from natural radioactive series of uranium, detected in the samples, were: ${ }^{234} \mathrm{Th},{ }^{214} \mathrm{~Pb}$ şi ${ }^{214} \mathrm{Bi}$ (the last two are descending from ${ }^{226} \mathrm{Ra}$, from the series of ${ }^{238} \mathrm{U}$ and ${ }^{226} \mathrm{Ra}$

\begin{tabular}{|c|c|c|c|}
\hline $\begin{array}{l}\text { D. Sample } 5 \text { - Bauxite residue (raw, } \\
\text { dried). The measurement in a plastic } \\
\text { Sarpagan type (diameter } 78 \mathrm{~mm} \text {, height } \\
42 \mathrm{~mm}) \text {, total mass sample }(0,1701 \pm \\
\pm 0,0005) \mathrm{Kg} \text {, measurement duration } \\
15.000 \mathrm{~s} \text {, on a plinth at a distance of } \\
1,6 \mathrm{~mm} \text { in the central position over } \\
\text { detector }\end{array}$ & $\begin{array}{l}\text { Natural radionuclide }{ }^{40} \mathrm{~K} \text { : } \\
\text { Natural radioactive series of } \\
\text { thorium }\left({ }^{232} \mathrm{Th}\right) \text { : } \\
\text { 226 Ra, from Natural } \\
\text { radioactive series of Uranium: }\end{array}$ & $\begin{array}{l}<\mathrm{AMD} * \\
18,4 \mathrm{~Bq} / \mathrm{kg} \\
36 \mathrm{~Bq} / \mathrm{kg} \\
(\text { on the reference data } \\
07.11 .2017,12: 00 \mathrm{UT})\end{array}$ & $\begin{array}{l} \pm 2,5 \mathrm{~Bq} / \mathrm{kg} \\
\pm 8 \mathrm{~Bq} / \mathrm{kg}\end{array}$ \\
\hline
\end{tabular}

Radionuclides from the natural radioactive series of torium detected in samples are: ${ }^{228} \mathrm{Ac}$ (emissions gamma radiations with $338 \mathrm{keV}$ ), ${ }^{212} \mathrm{~Pb},{ }^{212} \mathrm{Bi}$ and ${ }^{208} \mathrm{Tl}$. Radionuclides from the natural radioactive series of uranium detected in samples are: ${ }^{234} \mathrm{Th},{ }^{214} \mathrm{~Pb} s \mathrm{~s}^{214} \mathrm{Bi}$ (the last two are descendents of ${ }^{226} \mathrm{Ra}$, from series ${ }^{238} \mathrm{U}$ and ${ }^{226} \mathrm{Ra}$ 
Continuation of Table 4

\begin{tabular}{|c|c|c|c|}
\hline 1 & 2 & 3 & 4 \\
\hline $\begin{array}{l}\text { E. Sample } 6 \text { - Bauxite residue washed } \\
\text { and, dried). The measurement in a } \\
\text { plastic Sarpagan type (diameter } 78 \mathrm{~mm} \text {, } \\
\text { height } 42 \mathrm{~mm}) \text {, total mass sample } \\
(0,1606 \pm 0,0005) \mathrm{Kg} . \text {, measurement } \\
\text { duration } 24.000 \mathrm{~s} \text {, on a plinth at a } \\
\text { distance of } 1,6 \mathrm{~mm} \text { in the central } \\
\text { position over detector }\end{array}$ & $\begin{array}{l}\text { Natural radionuclide }{ }^{40} \mathrm{~K} \text { : } \\
\text { Natural radioactive series of } \\
\text { thorium }\left({ }^{232} \mathbf{T h}\right) \text { : } \\
{ }^{226} \mathrm{Ra} \text {, from Natural } \\
\text { radioactive series of Uranium: }\end{array}$ & $\begin{array}{l}5,2 \mathrm{~Bq} / \mathrm{kg} \\
26,9 \mathrm{~Bq} / \mathrm{kg} \\
42 \mathrm{~Bq} / \mathrm{kg} \\
\text { (on the reference data } \\
07.11 .2017,12: 00 \mathrm{UT} \text { ) }\end{array}$ & $\begin{array}{l} \pm 5,6 \mathrm{~Bq} / \mathrm{kg} \\
\pm 3,1 \mathrm{~Bq} / \mathrm{kg} \\
\pm 9 \mathrm{~Bq} / \mathrm{kg}\end{array}$ \\
\hline \multicolumn{4}{|c|}{$\begin{array}{l}\text { Radionuclides from the natural radioactive series of thorium detected in samples are: }{ }^{228} \mathrm{Ac} \text { (emissions gamma } \\
\text { radiations with } 338 \mathrm{keV}),{ }^{212} \mathrm{~Pb},{ }^{212} \mathrm{Bi} \text { and }{ }^{208} \mathrm{Tl} \text {. Radionuclides from the natural radioactive series of uranium } \\
\text { detected in samples are: }{ }^{234} \mathrm{Th},{ }^{214} \mathrm{~Pb} \text { and }{ }^{214} \mathrm{Bi} \text { (the last two are descendents of }{ }^{226} \mathrm{Ra} \text {, from series }{ }^{238} \mathrm{U} \text { and }{ }^{226} \mathrm{Ra}\end{array}$} \\
\hline $\begin{array}{l}\text { F. Sample } 3 \text { - Aluminum hydroxide. } \\
\text { The measurement in a plastic Sarpagan } \\
\text { type (diameter } 78 \mathrm{~mm} \text {, height } 42 \mathrm{~mm}) \\
\text { total mass sample }(0,2125 \pm 0,0010) \mathrm{Kg} \text {, } \\
\text { measurement duration } 26.500 \mathrm{~s} \text {, on a } \\
\text { plinth at a distance of } 1,6 \mathrm{~mm} \text { in the } \\
\text { central position over detector }\end{array}$ & $\begin{array}{l}\text { Natural radionuclide: }{ }^{40} \mathrm{~K}: \\
\text { Natural radioactive series of } \\
\text { thorium }\left({ }^{232} \mathrm{Th}\right): \\
{ }^{226} \mathrm{Ra} \text {, from Natural } \\
\text { radioactive series of uranium: }\end{array}$ & $\begin{array}{l}<\mathrm{AMD} * \\
<\mathrm{AMD} * \\
4.0 \mathrm{~Bq} / \mathrm{kg} \\
(\text { on the reference data } \\
07.11 .2017,12: 00 \mathrm{UT})\end{array}$ & $\pm 6.0 \mathrm{~Bq} / \mathrm{kg}$ \\
\hline \multicolumn{4}{|c|}{$\begin{array}{l}\text { Radionuclides from the natural radioactive series of thorium detected in samples are: }{ }^{228} \mathrm{Ac},{ }^{212} \mathrm{~Pb},{ }^{212} \mathrm{Bi} \text { şi } \\
\text { (208 } \mathrm{Tl} \text {. Radionuclides from the natural radioactive series of uranium detected in samples are: }{ }^{234} \mathrm{Th},{ }^{214} \mathrm{~Pb} \text { şi } \\
{ }^{214} \mathrm{Bi} \text { (the last two are descendents of }{ }^{226} \mathrm{Ra} \text {, from series }{ }^{238} \mathrm{U} \text { and }{ }^{226} \mathrm{Ra} \text { ) }\end{array}$} \\
\hline $\begin{array}{l}\text { F. Sample } 7 \text { - Alumina gamma. The } \\
\text { measurement in a plastic Sarpagan } \\
\text { type (diameter } 78 \mathrm{~mm} \text {, height } 42 \mathrm{~mm} \text { ), } \\
\text { total mass sample } 0,2032 \pm 0,0010) \mathrm{Kg} \text {, } \\
\text { measurement duration } 23.100 \mathrm{~s} \text {, on a } \\
\text { plinth at a distance of } 1,6 \mathrm{~mm} \text { in the } \\
\text { central position over detector }\end{array}$ & $\begin{array}{l}\text { Natural radionuclide: }{ }^{40} \mathrm{~K} \text { : } \\
\text { Natural radioactive series of } \\
\text { thorium }\left({ }^{232} \mathrm{Th}\right): \\
{ }^{226} \mathrm{Ra} \text {, from Natural } \\
\text { radioactive series of uranium: }\end{array}$ & $\begin{array}{l}<\mathrm{AMD} * \\
<\mathrm{AMD} * \\
15.0 \mathrm{~Bq} / \mathrm{kg} \\
(\text { on the reference data } \\
07.11 .2017,12: 00 \mathrm{UT} \text { ) }\end{array}$ & $\pm 6.0 \mathrm{~Bq} / \mathrm{kg}$ \\
\hline \multicolumn{4}{|c|}{$\begin{array}{l}\text { *AMD: minimum detectable activity in this case estimated to } 6,3 \mathrm{~Bq} / \mathrm{kg} \text { for }{ }^{40} \mathrm{~K} \text { and respectively, } 3,6 \mathrm{~Bq} / \mathrm{kg} \\
\text { for }{ }^{228} \mathrm{Ac} \text {, from series }{ }^{232} \mathrm{Th} \text { ). } \\
\text { Radionuclides from the natural radioactive series of thorium detected in samples are: }{ }^{228} \mathrm{Ac},{ }^{212} \mathrm{~Pb},{ }^{212} \mathrm{Bi} \text { şi } \\
\text { s08 } \mathrm{Tl} \text {. Radionuclides from the natural radioactive series of uranium detected in samples are: }{ }^{234} \mathrm{Th},{ }^{214} \mathrm{~Pb} \text { şi } \\
{ }^{214} \mathrm{Bi} \text { (the last two are descendents of }{ }^{226} \mathrm{Ra} \text {, from series }{ }^{238} \mathrm{U} \text { and }{ }^{226} \mathrm{Ra} \text { ) }\end{array}$} \\
\hline
\end{tabular}

The measurements were made by Horia Hulubei National Institute for R\&D in Physics and Nuclear Engineering (IFIN-HH).

\subsection{Aluminium hydroxide contamination by occlusion}

There are some simple mechanisms, which can explain how the metallic impurities contaminate the aluminium hydroxide. Sodium simply is found embedded in some stable forms by substitution of the aluminium ions in hydroxide crystal lattice. But, this happened only under specific conditions concerning supersaturation level and supersaturation variation rates. Actually, sodium can contaminate aluminium hydroxide in any stage of the aluminate decomposition process. Some of the other impurities follow, almost always, the same incorporation mechanism as sodium, but not at so lager scale as sodium, Moreover, the contaminated fractions are mobile and can get into the final product modified or unmodified, also in any stage of decomposition process. Identifying the source of these contaminated fractions is very important for removing the cause and raising the quality of aluminium hydroxide. 
The occluded fraction of soluble impurities happen mainly in the agglomeration process of polycrystalline particles by closing inside the polycrystalline aggregates some small drops of spent liquor, variable and non-uniformly dispersed as sizes and numbers. The incorporated droplets no longer communicate through open channels with the outside liquor and consequently, the intensive washings of aluminium hydroxide cannot remove (no matter how well the washing is done) the remaining spent liquor isolated in mass of the aggregated particles.

The lixiviated fraction of impurities is that part of impurities remaining on the surface of aluminium hydroxide particles as diluted spent liquor. Most of these impurities can be removed by washing and their concentration in the final product depends on the washing efficiency. A part of soluble fraction of impurities is generated by precipitation of organic acids as salts with metallic impurities, their chemical adsorption onto the particles surface, or their inclusion in the aluminium hydroxide crystals as sodium or of other metals compounds. Parts of these fractions may be dissolved in the washing stage, and the rest are locked in the crystalline lattice of aluminium hydroxide, and finally decomposes upon calcination releasing the impurities as oxides. It is possible that, at high concentrations of organic acids in the spent liquor, some organic acid salts to precipitate in the form of distinct crystals together with aluminium hydroxide. In this case, the advanced washing of the aluminium hydroxide particles may lead to the partial or total elimination of this form in impurity of the aluminium hydroxide [10].

Insoluble compounds or chemically bound impurities are fractions more active in contamination process than the soluble impurities. They can be occluded in the agglomerating particles in any stage of the aluminate liquors decomposition process. Also, they can promote predominantly the heteronucleation at smaller particle surface, shaping bridges that stabilize the polycrystalline aggregates in the agglomeration process. To prevent or at least control the contamination process by occlusion of insoluble compounds or chemically bound impurities it is necessary to identify the sources and to remove or alleviate their effect. Most of these contaminants are coming in the Bayer concentrated liquor and microscopic particles originate from bauxite mineralogical compounds or are born as crystalline phases during bauxite Bayer digestion stage.

Sierra Leone bauxite contains the following mineralogical components: Gibbsite $-\mathrm{Al}(\mathrm{OH})_{3}$; Goethite-alumina- $\left(\mathrm{Fe}_{(1-\mathrm{x})} \mathrm{Al}_{\mathrm{x}}\right) \mathrm{O}(\mathrm{OH})$; Hematite-alumina- $\left(\mathrm{Fe}_{(1-\mathrm{x})} \mathrm{Al}_{\mathrm{x}}\right)_{2} \mathrm{O}_{3} ;$ Kaolinite- $\mathrm{Al}_{4}(\mathrm{OH})_{8}\left(\mathrm{Si}_{4} \mathrm{O}_{10}\right)$; Quartz $-\mathrm{SiO}_{2} ; \mathrm{Zircon}-\mathrm{ZrSiO}_{4} ; \mathrm{Ilmenite}-\mathrm{FeTiO}_{3}$; Anatase $-\mathrm{TiO}_{2}$; and calcium, potassium, magnesium, phosphorus, vanadium and other minor components as mineral salts. Bauxite residue contains the same mineralogical phases as bauxite, but in other ratios and the new born phases: sodalite $-\mathrm{Na}_{8}\left(\mathrm{Al}_{6} \mathrm{Si}_{6} \mathrm{O}_{24}\right)$ $\mathrm{Cl}_{2}$, katoite $-\mathrm{Ca} 3 \mathrm{Al} 2(\mathrm{SiO} 4)(\mathrm{OH}) 8$, and magnetite $-\mathrm{Fe}_{2} \mathrm{O}_{4}$. All these materials contain crystalline phases and amorphous phases (20-40\%). Also, the new born phases can be well crystallized and amorphous or at least, bearing poor crystalized structures.

The morphology and elemental composition of the particulate material samples (bauxite, bauxite residue and aluminium hydroxide) were characterized by scanning electron microscopy (SEM: Quanta FEG 250, FEI, The Netherlands) using back scattered electron detector (BSD) coupled with energy dispersive X-ray spectroscopy (EDS): using Apollo SSD detector, EDAX Inc. US). The microstructure and EDS analysis were performed at about $10 \mathrm{~mm}$ working distance (WD) in low vacuum mode in order to avoid surface charging and damage of the analysed material.

SEM microscopy coupled with EDX spectroscopy is an effective tool for detecting impurities in any natural material or manufactured by any technology. Furthermore, the method allows identifica- 
tion of the source and procedures to avoid impurification by controlling the technology in the original stage where the source is contaminating the aluminium hydroxide particles. This ultimate advantage has led to the application of SEM microscopy coupled with EDX spectroscopy to the analysis of unmilled and milled aluminium hydroxide samples. The results and conclusions of the study are presented below.

Microscopic analysis concerns three samples from the fractions of dried, milled and classified aluminium hydroxide. Its about the fractions: $0=10$ microns, $0-20$ microns and $0-45$ microns. Initially, some suspicions were raised about possible segregation of the contaminated particles and their accumulation in the smallest fractions. But this event did not have occurred very often under our experimental circumstances.

In the Fig. 3 and Fig. 4 there are given the micrographs of two particles of aluminium hydroxide with high purity. These samples should be the reference material in good choice of the process operation parameters. In the real Bayer process the aluminium hydroxide particles are carrying always smaller quantities of $\mathrm{Na}_{2} \mathrm{O}$, accounting for $0.3-0,4 \%$, and only under very careful conditions the $\mathrm{Na}_{2} \mathrm{O}$ could be dropped under $0.3 \%$. As was mentioned before some poor crystallized or amorphous mineral phase from bauxite (non full reacted mass) and bauxite residue are always prone to deliver mobile reactive molecular entities, which can be quickly occluded into the aluminium particles in any stage of their growth.

There are a lot of mineralogical phases in Bayer cycle. Some of them are well crystallized, with distinctive crystalline faces of various sizes. Other are dispersed as smaller crystals in the liquors of
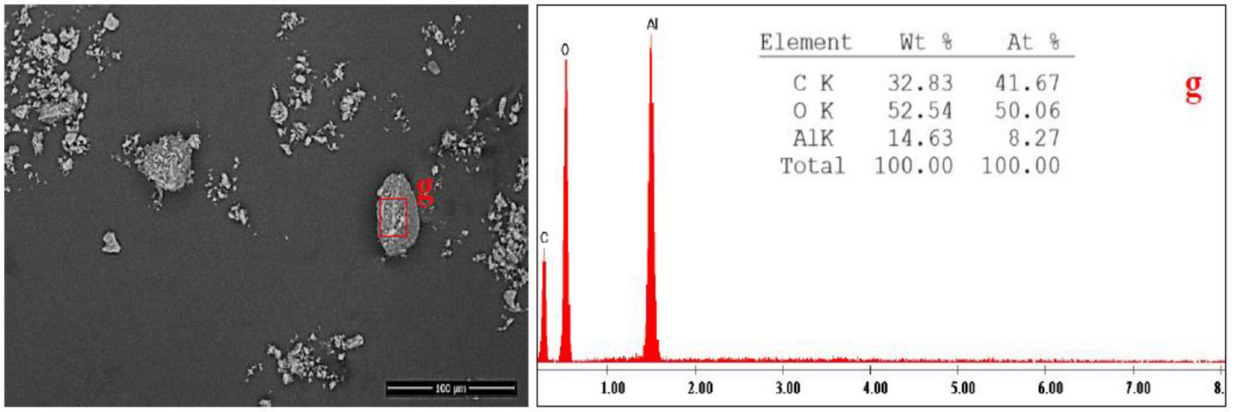

Fig. 3. SEM image of a pure $\mathrm{Al}(\mathrm{OH})_{3}$ particle from class $\mathrm{ATH}<10 \mu \mathrm{m}$
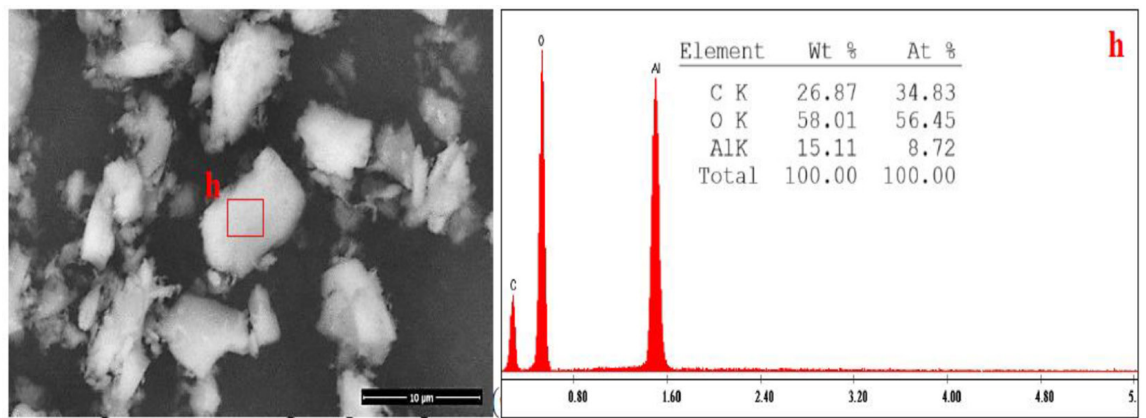

Fig. 4. SEM image of a pure $\mathrm{Al}(\mathrm{OH})_{3}$ particle from class $\mathrm{ATH}<20$ 

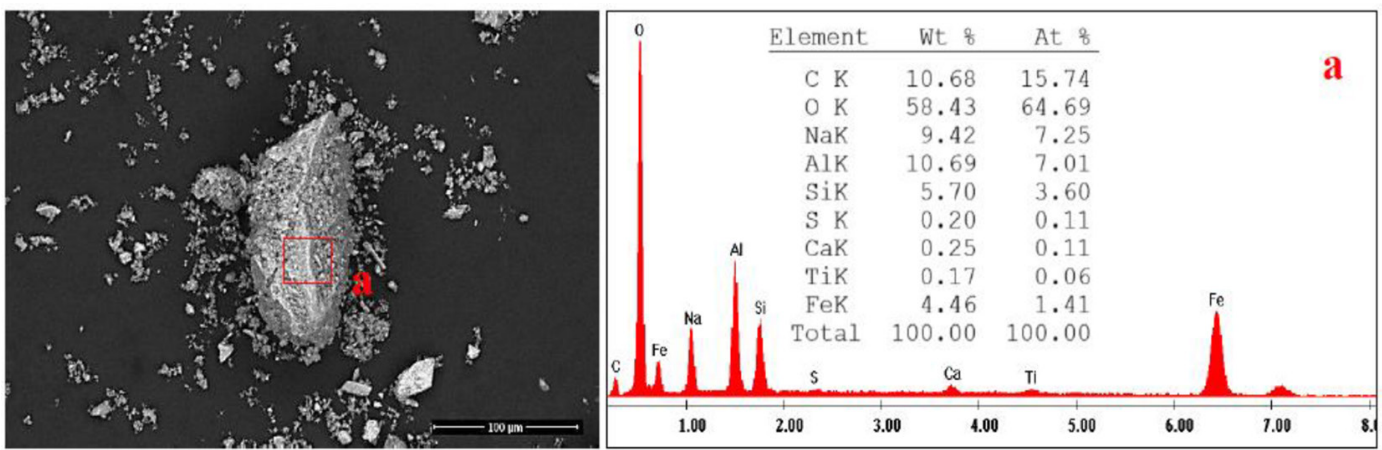

Fig. 5. Morphology of a particle of sodalite from bauxite residue investigated by diffraction EDS on a surface of $10 \mu \mathrm{m}^{2}$, magnification 1.000x; SEM image of a well crystallized sodalite particle (new born phase) with $\mathrm{Fe}_{2} \mathrm{O}_{3}$ inclusions and contaminated with $\mathrm{S}$ (as sulphate), and occluded with calcium and titanium compounds
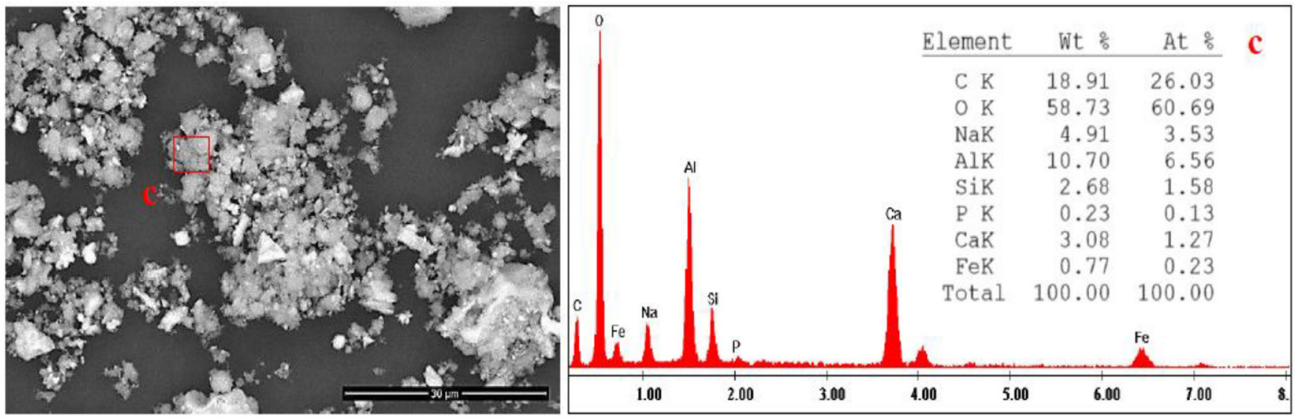

Fig. 6. Morphology of a particle of mixed sodalite and katoite agglomerate from bauxite residue investigated by diffraction EDS on a surface of $2 \mu \mathrm{m}^{2}$, magnification $10.000 \mathrm{x}$; SEM image of the incompletely crystallized cancrinite and sodalite agglomerates

different origins. In the Fig. 5 is visualized a large (100 microns) well mechanical stabilized crystal of sodalite (born in Bayer concentrated liquors during the bauxite digestion), surrounded by small crystalline or non-crystalline agglomerated small particles. The larger crystal itself is not a contaminating phase, because it has little chance to travel through the clarification and Bayer liquor filtration stages. But the particle hundreds of time smaller have the opportunity to overpass the control filter and to be occluded in the aluminium hydroxide particles, during growth and agglomeration stages. Actually, most of the smaller particles around the sodalite big crystal are, also, particles of sodalite contaminated with $\mathrm{Ca}, \mathrm{TiO}_{2}$ and $\mathrm{S}$ (sulphate) as soluble or insoluble salts and occluded by $\mathrm{Fe}_{2} \mathrm{O}_{3}$.

In the Fig. 6 there is presented another kind of agglomerated particles containing sodalite and katoite. Both of these phases are born in the digestion stage of bauxite, which was processed with some $\mathrm{CaO}$ adding for increasing stability of the agglomerated particle. Similar associations with variable calcium content were found often in the bauxite residue left after Sierra Leone bauxite digestion process. But in this case (Fig. 6), the agglomerated particle structure seems to be more fragile. Probably, the agglomeration of the smallest particles is an unfinished process, or katoite crystallization did not reach its final stages. This is why particles like those in the Fig. 6 are active sources of material for occlusion of the aluminium hydrate in Bayer production line. A strange association of particles can be seen in the Fig. 7. Here a particle of alumino-goethite or alumino-hematite (from bauxite) is covered 
with a layer of sodalite (born during, bauxite digestion process). This kind of particles are not sources of material for occlusion, because at the dimensions and mechanical stability, seen in the Fig. 7, its particle is captured in Bayer concentrate liquor filter cake.

Figures 8 and 9 are good examples of aluminium hydroxide particle heavy contamination with the silicon (as silicon dioxide) and iron (as alumino-goethite or alumino-hematite) (Fig. 8) and with
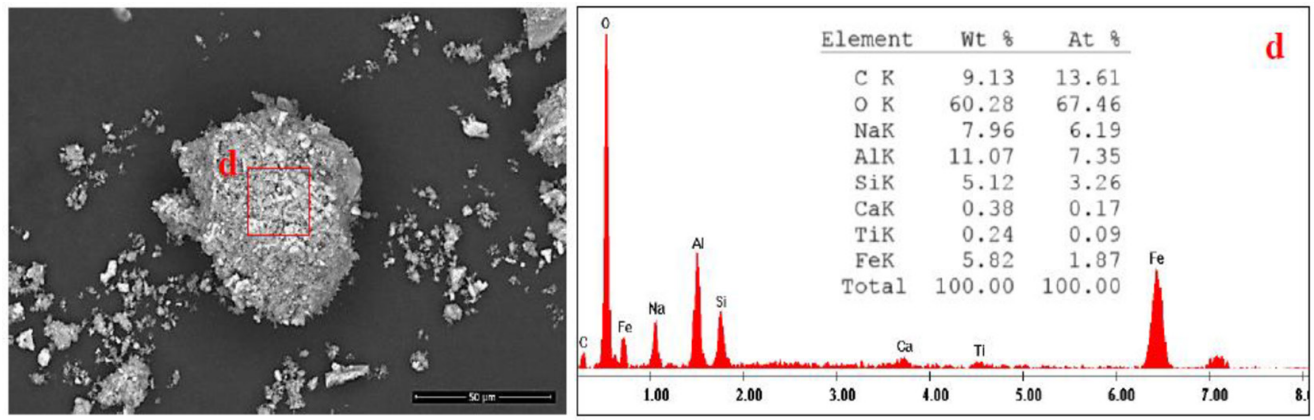

Fig. 7. Morphology of a large agglomerate of sodalite from bauxite residue and other impurities investigated by diffraction EDS on a surface of $20 \mu \mathrm{m}^{2}$, magnification 2.000x; SEM image of incompletely crystallized cancrinite and sodalite in a large agglomerates
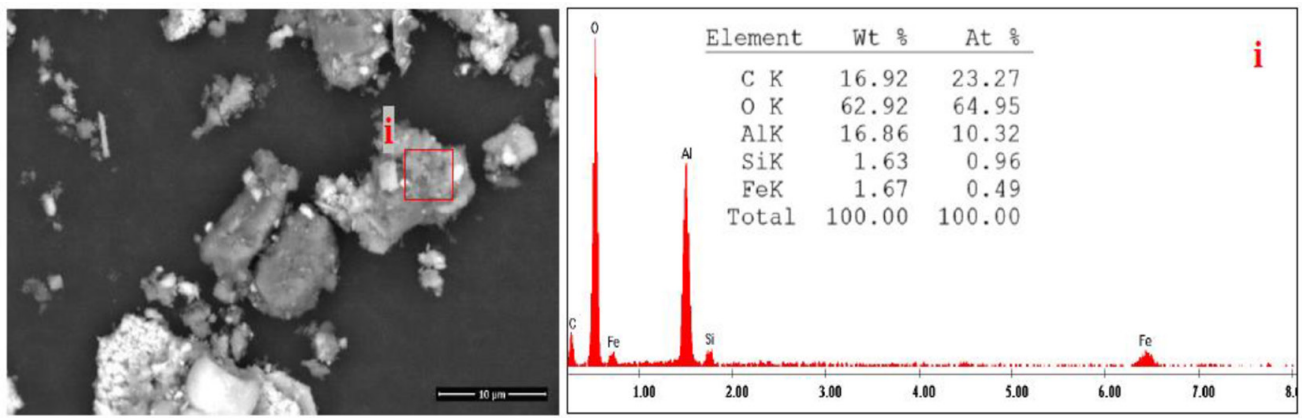

Fig. 8. Morphology of a small particle of aluminium hydroxide from fraction $0-45 \mu \mathrm{m}$ investigated by diffraction EDS on a surface of $4 \mu \mathrm{m}^{2}$, magnification 8.000x; SEM image of an occluded $\mathrm{Al}(\mathrm{OH})_{3}$ particle with $\mathrm{Fe}_{2} \mathrm{O}_{3}$ and $\mathrm{SiO}_{2}$
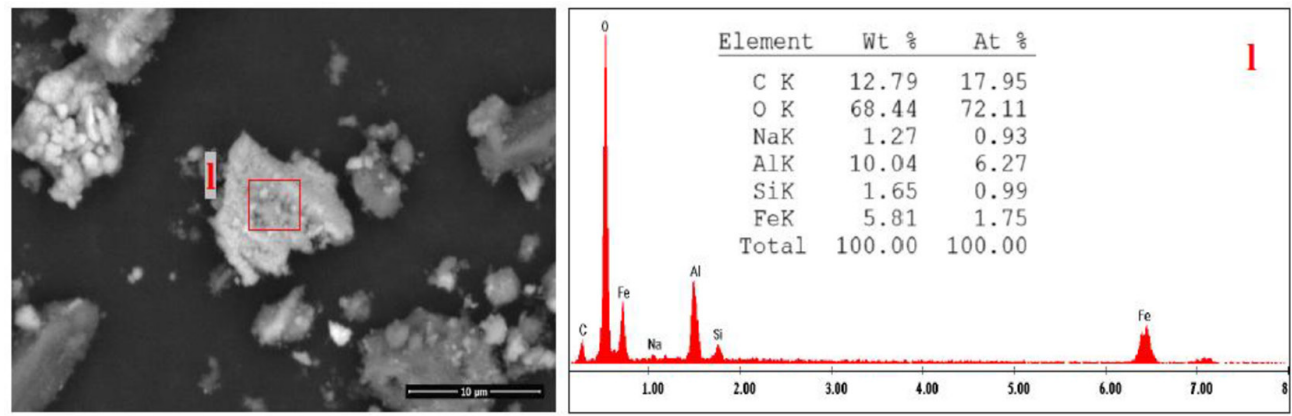

Fig. 9. Morphology of a small particle of aluminium hydroxide from fraction $0-45 \mu \mathrm{m}$ investigated by diffraction EDS on a surface of $2 \mu \mathrm{m}^{2}$, magnification $10.000 \mathrm{x}$; SEM image of a contaminated $\mathrm{Al}(\mathrm{OH})_{3}$ particle occluded after the breakage of sodalite particles in the presence of iron from alumino-goethite or alumino-hematite 
residuals from the breakage of sodalite particles (Fig. 9). According to the above figures, it should be concluded that the new born phases in bauxite digestion process with perturbed lattices or as disordered crystals are active precursors for the impurities occlusion in aluminium hydroxide particles in any stage of sodium aluminate decomposition process in Bayer technology.

\section{Conclusions}

Some of the properties of processed bauxite have a major importance in the transfer of heavy metals in liquors and in bauxite residue. Of these, the most important are: a) Crystallinity and the degree of crystallinity of all mineralogical phases in bauxite (including minor phases with heavy metal content); b) The weight percent of the amorphous phase, the distribution of the particle size in the digestion phase; c) Temperature in the digestion stage, fluctuation intervals of the major components concentration in the liquors during digestion; d) Operating parameters in the predesilication stage and the crystallinity of the new born DSP in this stage, and the crystallinity of other new or old natural phases; e) Efficiency of the concentrated liquors clarification additives; f) fineness and activity/ efficiency of TCA in the filtering stage of the concentrated liquors.

\section{Acknowledgement}

This study was made possible by implementation of the «Endow the research and Development of SC ALUM SA with independent and efficient research facilities to support the economic competitiveness and business development» project, co-funded by the European Regional Development Fund through the Competitiveness Operational Program 2014-2020. Under this project were purchased and commissioned: «Independent equipment/Installation for research and development of the technology of wet aluminium hydroxide classification», «Independent equipment/Installation for research and development of technology to obtain the dried aluminium hydroxide» and «Independent equipment/ Installation for research and development of the technology of grinding and screening the dried aluminium hydroxide».

\section{References}

[1] Dobra G., Filipescu L., Anghelovici N., Alistarh V., Iliev S. Bauxite residue safety disposal and friendly environmental processing permanent care at Vimetco Alum SA Tulcea, Bauxite Residue Valorisation and Best Practices Conference, Leuwen 2015, 47-52.

[2] Dobra G., Kiselev A., Filipescu L., Alistarh V., Anghelovici N., Iliev S. Full analysis of Sierra Leone bauxite and possibilities of bauxite residue filtration. J. Sib. Fed. Univ. Eng. Technol., 2016, 9(5), 643-656.

[3] Dobra G., Filipescu L., Anghelovici N., Alistarh V., Iliev S., Cotet L. Bauxite residue safety disposal and possibilities to further utilization. Part 1. Acid soils remediation, J. Sib. Fed. Univ. Eng. Technol., 2017, 10(1), 6-21.

[4] Cui Y., Chen J., Zhang Y., Peng D., Hung T., Sun C. pH-Dependent Leaching Characteristics of Major and Toxic Elements from Red Mud, Int J. Environ Res Public Health 2019, 16(11): 2046, DOI: 10.3390/ijerph16112046

[5] Niculescu M., Ionita A.D., Filipescu L. Chromium Adsorption on Neutralized Red Mud, Rev. Chimie (Bucuresti) 2010, 61(2), 200-205. 
[6] Niculescu M., Ionita A.D., Simion D., Crudu M., Filipescu L. Red mud - new material for tannery residual chromium binding, UPB Sci. Bull. Series Chemistry 2010, 72 (3), 99-114.

[7] Rubinos D.A., Barral M.T. Fractionation and mobility of metals in bauxite red mud, Environmental Science and Pollution Research January 2013, DOI: 10.1007/s11356-013-1477-1474.

[8] Micó C., Peris M., Sánchez J., Recatalá L. Heavy metal content of agricultural soils in a Mediterranean semiarid area: the Segura River Valley (Alicante, Spain), Spanish Journal of Agricultural Research 2006, 4(4), 363-372.

[9] Tóth G., Hermann T., Da Silva M.R., Montanarella L. Heavy metals in agricultural soils of the European Union with implicationsfor food safety, Environment International 2016, 88, 299-309.

[10] Dobra G., Iliev S., Anghelovici N., Cotet L., Filipescu L. Impurities accumulation on the surface of alumina hydrate particles in Bayer technology, Rev Chimie (Bucharest) 2019, 70 (2), 355360.

[11] Vind J., Alexandri A., Vassiliadu W., Panias D. Distribution of Selected Trace Elements in the Bayer Process, Metals 2018, 8(5), 32.

[12] Éimear A., Deady E.A., Mouchos E., Goodenough E., Williamson B.J., Wall F. A review of the potential for rare-earth element resources from European red muds: examples from Seydişehir, Turkey and Parnassus-Giona, Greece. 